Type: Article Research

\title{
RELASI ISLAM-KRISTEN: STUDI KASUS DI DESA TEGALOMBO, PATI, JAWA TENGAH
}

\author{
Ghufron Ghufron \\ Universitas Islam Negeri (UIN) Syarif Hidayatullah Jakarta \\ Email: ghufron2013@gmail.com
}

\begin{abstract}
Abstrak
Tulisan ini ingin membangun sebuah model alternatif dalam merawat kerukunan antar-umat beragama. Model tersebut dapat ditemukan melalui mekanisme kultural yang terjadi pada relasi Islam-Kristen di Desa Tegalombo, Pati Jawa Tengah. Fondasi kerukunan dua agama tersebut bertumpu pada keberlanjutan tiga model harmoni, yaitu: Pertama, do'a lintas agama dalam hajatan keluarga atau level desa; Kedua, budaya saling kunjung saat hari raya, ketika ada yang sakit, dan saling mengantar makanan sebagai bentuk menyambung harmoni. Ketiga, dialog model praktis dalam forum Selapanan yang mempertemukan dua kelompok agama dalam rangka mendiskusikan berbagai masalah keamanan dan pembangunan sosial. Di sisi lain, hubungan keduanya juga memantik ketegangan yang dipicu kontestasi perebutan dominasi penyiaran agama dengan teknik-teknik tertentu seperti pengajian (Islam) dan Kebaktian Kebangunan Rohani (Kristen).
\end{abstract}

Kata Kunci: Islam-Kristen, Kontestasi, Konflik dan Perdamaian, dan Relasi.

\begin{abstract}
This paper wants to build an alternative model for caring for inter-religious harmony. The model can be found through the cultural mechanism that occurs in Islamic-Christian relations in Tegalombo Village, Pati, Central Java. The foundation of harmony between the two religions rests on the sustainability of three harmony models, namely: First, interfaith prayer in the celebration of family or village level; Second, culture visits each other during feast days, when someone is sick, and the interfood sharing as a form of connecting harmony. Third, practical model dialogue in the Selapanan forum that brings together two religious groups in order to discuss various issues of security and social development. On the other hand, the relationship between the two also triggered a tension triggered by the contestation over the dominance of religious broadcasting with certain techniques such as recitation (Islam) and Revival Service (Christian).
\end{abstract}

Key Words: Muslim-Christian, Contestation, Conflict and Peace, and Relation.

\section{Pendahuluan}


Konflik dan kekerasan yang mengatasnamakan kepentingan agama, terutama Islam dengan Kristen hampir mewarnai seluruh generasi, mulai dari Perang Salib ${ }^{1}$ hingga berbagai perusakan tempat ibadah di berbagai tempat. Di Indonesia, cerita kelam ini dibingkai dalam terminologi khusus SARA (Suku, Agama, Ras, dan Antar Golongan) yang menandakan bahwa isu agama menjadi salah satu isu yang rentan memicu konflik.

Sejarah mencatat, konflik antar kelompok agama dan keyakinan yang melahirkan tindakan kekerasan memang masif terjadi paska kejatuhan Orde Baru (1998) yang mencapai rata-rata lebih dari 200 kasus setiap tahun. ${ }^{2}$ Istilah kekerasan berbasis agama, menurut Sumanto Al Qurtuby, tidak hanya mengacu pada apa yang dirumuskan Johan Galtung sebagai direct/physical violence, seperti kerusuhan, penyerangan, pengerusakan, pembakaran, dan lainnya, melainkan juga kekerasan kultural atau kekerasan simbol (Pierre Bourdieu) berupa pelecehan, stigmatisasi, penghinaan, dan penyesatan terhadap kelompok agama/kepercayaan tertentu. ${ }^{3}$

Terjadinya benturan antar agama di Indonesia, khususnya Islam dan Kristen, bermula dari sikap tertutup masing-masing tentang agenda dakwah dan isu konversi. Kedua agama besar ini mempunyai perhatian dan doktrin terhadap dakwah atau misi, dan pada titik itulah keduanya berpotensi saling bertabrakan. ${ }^{4}$ Menyadari bahwa konflik antar umat beragama dan problem diskriminasi terhadap kelompok minoritas beragama adalah persoalan serius, berbagai pihak terus membangun resolusi konflik melalui dialog dan pendampingan sosial. ${ }^{5}$ Namun, jalan dialog mendapat kritik karena tidak pernah ada evaluasi untuk melihat capaian serta tantangan ke depan.

1Perang ini dikobarkan Paus Urban II, 25 November 1095 di Konsili ClermontLihat Karen Amstrong, Holy War: The Crusades and Their Impact on Today World (New York: Anchor Books, 2001), 27.

2SETARA Institute melaporkan bahwa dalam kurun 2007-2009 terjadi 817 kasus pelanggaran kebebasan beragama dan berkeyakinan di Indonesia dengan perincian tahun 2007 terjadi 185 kasus, tahun 2008 terjadi 367 kasus dan tahun 2009 terjadi 265 kasus. Baca Ismail Hasani, Radikalisme Agama di Jabodetabek \& Jawa Barat (Jakarta: Publikasi Setara Institute, 2011). Wahid Institute mencatat pada tahun 2010-2013 terjadi sebanyak 977 kasus dengan perincian tahun 2010 terjadi 187 kasus, tahun 2011 terjadi 267 kasus, 2012 terjadi 278 kasus, dan di tahun 2013 terjadi 245 kasus. Dikutip dari http://www.wahidinstitute.org/wi-id/laporan-dan-publikasi/laporan-tahunan-kebebasan-beragamadan-berkeyakinan.html diakses pada 11 Februari 2014.

3Sumanto Al Qurtuby, "Pluralisme, Dialog dan Peace Building Berbasis Agama di Indonesia", dalam Elza Peldi Taher (ed), Merayakan Kebebasan Beragama: Bunga Rampai 70 Tahun Johan Effendi (Jakarta: ICRP bekerjasama dengan Penerbit Kompas, 2009), 186-187.

"Barbara Brown Zikmund "Dialog Agama-Agama dalam Konteks Misionarisme Baru", dalam Komarudin Hidayat dan Ahmad Gaus AF (ed.), Passing Over: Melintasi Batas Agama (Jakarta: Gramedia dan Paramadina, 1998), 25.

${ }_{5}$ Mengenai advokasi terhadap kelompok minoritas beragama di Indonesia, bisa dibaca dalam Syamsul Arifin dan Nafik Muthohirin. "The Viewpoint of the Young Muhammadiyah Intellectuals Towards the Religious Minority Groups in Indonesia". TEOSOFI: Jurnal Tasawuf dan Pemikiran Islam. Vol.9 No. 2. Desember, 2019, 282-305. 
Pendekatan dialog dalam membangun relasi yang harmonis antar agama seharusnya memang lebih banyak memberikan porsi pada pendekatan budaya, atau mekanisme kultural masyarakat yang banyak mendiskusikan hal-hal praktis menyangkut persoalan bersama, seperti kemiskinan, pendidikan dan lain sebagainya. Pemikiran tersebut sebenarnya sudah mengemuka sejak 1978, namun pada tataran implementasi masih mendapati berbagai hambatan. Model pendekatan dialog praktis dan mekanisme budaya dalam membangun relasi harmonis antar umat beragama dapat dilihat dari konteks Desa Tegalombo, Kabupaten Pati.

Mekanisme kultural atau budaya dalam membangun dialog praktis yang inklusif tersebut merupakan pencapaian atas proses panjang antara kelompok Islam dan Kristen dalam menyemai toleransi antar agama yang berbasis pada kekuatan nilai-nilai budaya atau kearifan. Budaya di Tegalomombo memberikan ruang bagi bertemunya kedua kelompok berbeda dalam tindakan sosial yang bertendensi teologis. Namun model relasi yang harmonis Islam-Kristen ini bukanlah sesuatu yang instan, melainkan terbangun melalui pergumulan atau dinamika hubungan yang cukup panjang.

Perjumpaan Islam-Kristen di Tegalombo sudah berlangsung pada era kolonialisme Belanda, dimana umat Islam pada umumnya mengangap agama Kristen sebagai agama yang disebarkan oleh Kolonial Belanda. Umat Islam langsung bereaksi keras terhadap misi Kristen sebagaimana sikap keras mereka juga terhadap kolonialisme. Perlawanan keras dari umat Islam ini memicu pemerintah Kolonial Belanda dan misionaris untuk saling dukung. Puncaknya, pada tahun 1854 Kolonial Belanda mengeluarkan dekrit atau peraturan yang mengatur penginjilan. Keberpihakan Kolonial Belanda terhadap gereja kian memperburuk hubungan kelompok Islam dan Kristen.

Jika Kolonial Belanda menganak-emaskan Kristen, sebaliknya pada masa penjajahan Jepang umat Islam mendapat angin segar untuk mengembangkan agama, termasuk organisasiorganisasi yang berbasis Islam. Pada masa ini gerak misionaris Kristen dibatasi bahkan mengalami stagnasi. ${ }^{6}$ Ketegangan antara kelompok Islam dan Kristen mencuat kembali pada paska tahun 1965 yaitu setelah meletusnya peristiwa Gerakan 30 September Partai Komunis Indonesia (G 30 S PKI). Paska peristiwa ini, ada konversi besar-besaran mantan anggota PKI atau orang yang dituduh terlibat dalam organisasi di bawah PKI melakukan konversi ke agama Kristen. ${ }^{7}$

Sejarah kontestasi dan juga kekerasan antara kelompok Islam dan Kristen tersebut lantas mendorong para tokoh agama dan juga masyarakat mencari fomat membangun kerukunan umat beragama. Budaya menjadi media yang utama untuk dijadikan ruang membangun kembali komunikasi, interaksi dan kerjasama antar pemeluk agama tersebut.

6Harry J. Benda, Bulan Sabit Matahari Terbit (Jakarta: Pustaka Jaya, 1985), 154.

${ }^{7}$ Wawancara awal dengan Siti Aminah (79 tahun) di Tegalombo pada 20 Juli 2011. Baca Mujiburrahman, Feeling Threatened: Muslim-Christian Relations in Indonesia's New Order (Leiden: Amsterdam University Press, 2006) 18, 29, 32-34, 89, 105-107. 
Pentradisian relasi agama yang harmonis berangkat dari pengalaman keagamaan masyarakat dan juga karena pengaruh tindakan tokoh agama yang diyakini sebagai terjemahan ajaran agama. Tindakan tersebut misalnya saat tokoh dari kedua agama memimpin sebuah hajatan tertentu seperti perkawinan. Jika keluarga yang mempunyai hajat Kristen, ketika pendeta akan memimpin do'a terlebih dulu mempersilahkan umat Muslim (termasuk kyai) untuk memanjatkan doa secara Islam. Sebaliknya saat hajatan keluarga Muslim, kyai yang memimpin do'a mempersilahkan yang beragama Kristen untuk berdo'a sesuai keyakinannya.

Fenomena relasi keduanya seperti dalam beberapa contoh di atas telah menjangkau banyak aspek kehidupan sosial dan lebih dari persoalan solidaritas dan saling menghargai. Relasi tersebut bahkan memenuhi apa yang oleh Michael Walzer disebut sebagai koeksistensi damai (peaceful coexistence), dimana kelompok yang berbeda secara identitas menyemai toleransi. ${ }^{8}$ Masyarakat Tegalombo memiliki mekanisme tertentu untuk menjembatani persoalan konsep teologis dan keinginan hidup berdampingan secara damai yang dipengaruhi oleh kemampuan mengkombinasikan konsep tentang keyakinan agama dan konsep tentang hubungan sosial-budaya. Inilah yang dimaksud Nurcholis Madjid sebagai "pertalian sejati kebhinekaan dalam ikatan keadaban" (genuine engagement of diversity within the bond of civility) $)^{9}$ dan bukan lagi sekedar "kebaikan negatif" yang hanya untuk sekedar menyingkirkan fanatisme.

\section{Tegalombo, Persil Kristen dalam Kepungan Muslim}

Hal yang sering dibicarakan dalam konteks perkembangan Kristen di Indonesia pada awal sejarahnya adalah terkait evangelisme (penginjilan atau pekabaran Injil) atau misionarisme (penyebaran agama Kristen) yang mengikuti garis perdagangan dan kolonialisme Belanda. Nama misionaris pribumi Jawa yang terkenal dan berpengaruh di karisidenan Pati adalah Kiai Ibrahim Tunggul Wulung. Ajaran tokoh ini kemudian dikenal dengan ajaran Kristen Jowo, yang menggabungkan ajaran Kristen dengan tradisi Jawa. Sedangkan dari misionaris Belanda adalah Pieter Jansz dari misionaris DZV (Doopsgezind Zendings Vereeniging) yang ajarannya kemudian dikenal dengan Kristen Mennonit. ${ }^{10}$

${ }^{8}$ Michael Walzer, On Toleration (New Haven and London: Yale University, 1997), 2.

"Nurcholis Madjid, "Masyarakat Madani dan Investasi Demokrasi: Tantangan dan Kemungkinan", dalam Ahmad Baso, Civil Society versus Masyarakat Madani: Arkeologi Pemikiran "civil Society" dalam Islam Indonesia, (Jakarta: Pustaka hidayah, 1999), 22. Lihat juga dalam Elza Peldi Taher (Ed.), Merayakan Kebebasan Beragama; Bunga Rampai Menyambut 70 Tahun Djohan Effendi (Diterbitkan atas kerjasama ICRP dengan Kompas, Jakarta: 2009), 119.

${ }^{10}$ Mennonit merupakan sebuah aliran dalam gereja sebagai penerus gerakan Anabaptis di jaman reformasi Gereja di Barat. Nama Mennonit diambil dari nama tokoh gerakan anabaptis (memperhatikan baptisan) di Belanda yaitu Menno Simons. Aliran ini menekanka pada adanya rahmat Allah yang dihayati dala cara hidup yang baru seturut dengan ajaran Yesus. Lihat Sukoco dan Lawrence M. Yoder, Tata Injil di Bumi Muria (Semarang: Pustaka Muria, 2010), 11-12. 
Tunggul Wulung lahir di Bangsa wilayah kawedanan Juwana, Pati pada tahun 1800 dengan nama kecil Ngabdullah. ${ }^{11}$ Dalam catatan Danang Kristiawan, asal-usul sosok ini cukuplah misterius. Dia mengungkapkan bahwa tradisi lisan masyarakat sekitar wilayah Muria-lah yang banyak memberikan gambaran tentang Tunggul Wulung, meskipun cerita-cerita tersebut berbaur dengan sisi mitologi. ${ }^{12}$ Dalam tradisi lisan tersebut, Tunggul Wulung dulunya bernama Raden Mas Tondo yang berasal dari Keraton Solo yang menjadi Demang di Kediri dengan gelar Raden Mas Demang Padmodirdjo. Ia dianggap tidak loyal terhadap keraton karena turut andil atau terlibat dalam Perang Jawa, bersama Diponegoro melawan Belanda pada 1825-1830.13

Setelah Belanda berhasil mematahkan perlawanan Diponegoro, Ia meninggalkan keraton untuk melarikan diri dari kejaran Belanda. Ia memilih desa Ngalapan-Juwana sebagai tempat persembunyiannya karena dirasa aman. Agar persembunyianya tidak dikenali, ia hidup membaur dengan penduduk setempat dengan mengganti namanya menjadi Amat Dullah.

Pada 1840, akibat kesulitan ekonomi pada masa penerapan tanam paksa oleh Belanda, ia meninggalkan Juwana menuju Kediri, Jawa Timur untuk melakukan semedi (madeg pandhito) di Gunung Kelud bersama dengan istrinya. Setelah menjadi petapa ia mengganti namanya dengan Tunggul Wulung, sebuah nama yang diambil dari nama panglima legendaris Raja Jayabaya Kediri yang memerintah pada abad $12 .{ }^{14}$ Kemudian ia dan istrinya turun gunung dan bertemu dengan para misionaris utusan NZG (Nederlandsche Zendelingen Genootschap), dimana salah satunya adalah Jellesma yang membaptis Tunggul Wulung pada Juli 1857 dengan nama Ibrahim. ${ }^{15}$

Setelah pembaptisan, Tunggul Wulung melakukan kegiatan pekabaran injil di desa Bondo, Kabupaten Jepara. Ia sering pergi ke daerah-daerah sekitar Muria untuk membuka desa-

${ }^{11}$ Banyak sumber yang menyebutkan bahwa 1800 adalah tahun kelahiran Tunggul Wulung. Lihat Jan. S. Aritonang, Sejarah Perjumpaan Kristen dan Islam di Indonesia (Jakarta: BPK Gunung Mulia,2004), 93.

${ }^{12}$ Danang Kristiawan, "Mistisme dan Pembebasan Kyai Ibrahim Tunggul Wulung", Makalah di http://elsaonline.com/?p=1607 diakses pada 14 Februari 2015.

${ }^{13}$ Lawrence M. Yoder, The Introduction and Expression of Islam and Christianity in the Cultural Context of North Central Java (Michigan: University Microfilms International, 1987) hlm. 285.

${ }^{14}$ Nama Tunggul Wulung sangat populer bagi masyarakat kediri dan wilayah-wilayah di sekitar Gunung Kelud. Ia adalah Jendral Agung Raja Joyoboyo yang memerintah kerajaan di Kediri. Baca Danang Kristiawan, "Mistisme dan Pembebasan Kyai Ibrahim Tunggul" Wulung, Makalah di http://elsaonline.com/?p=1607 diakses pada 14 Februari 2015., dan Aritonang, Sejarah Perjumpaan Kristen dan Islam di Indonesia, 93.

${ }_{15}$ Pemilihan Ibrahim sebagai nama baptisnya memiliki makna simbolis, mengingat Ibrahim atau Abraham adalah bapa bagi banyak bangsa. Artinya ia juga berharap dapat menjadi bapa bagi orang banyak. Jan S. Aritonang, Sejarah Perjumpaan Kristen dan Islam di Indonesia, (Jakarta: PT BPK Gunung Mulia, 2004), 94. 
desa Kristen baru. Banyak orang tertarik ajarannya dan menyebut jemaatnya sebagai jemaat Kristen Jowo yang berbeda dengan jemaat Kristen versi Zending atau Kristen Eropa yang disebutnya sebagai Kristen Londo. ${ }^{16}$ Menurut Tunggul Wulung bangsa yang menjadi Kristen harus mempunyai pemimpinnya sendiri, sehingga tidak perlu menggabungkan diri dengan misionaris Belanda dan kemudian Kristennya bercorak Belanda. ${ }^{17}$

Bagi Soekoco, ada kesan bahwa ajaran Tunggul Wulung mirip dengan konsep Islam. Misalnya terkait dengan pengakuan Iman yang mirip sahadad, Doa Bapa Kami sebagaimana alfatihah, dan Dasa Titah yang mirip konsep rukun Islam. ${ }^{18}$ Kemiripan dengan bentuk ajaran Islam semakin jelas dengan pengadopsian tahlilan Islam menjadi Kristen melalui pengubahan pelafalan sebagaimana yang dilakukan Coolen di Jawa Timur, "la illah la illalah, Yesus Kristus Putra Allah". ${ }^{19}$ Selain itu praktik-praktik ritual seperti slametan, kenduren, maupun sunat yang menjadi corak Islam Jawa mendapat tempat dalam ajaran Tunggul Wulung. ${ }^{20}$

Ketika berhasil menyebarkan Kristen Jowo di Bondo (Jepara) dan sekitarnya dia melanjutkan pekabaran Injil di lingkungan masyarakat luas, termasuk masyarakat Islam. Pada 1878, dia mengirim muridnya, Benyamin Djojotruno tinggal di Tegalombo yang berjarak sekitar $5 \mathrm{~km}$ dari desa Banyutowo sebagai proses penjajagan sebelum melakukan misi pengkabaran injil. Saat itu, Tegalombo dan desa-desa sekitar kecamatan Dukuhseti adalah basis Islam, sehingga misi tersebut mendapat perlawanan dari masyarakat Islam. Akibatnya Benyamin dan beberapa pengikutnya meninggal. ${ }^{21}$ Pengikutnya bubar dan tidak berani lagi tinggal di Tegalombo.

Kegagalan misi Benyamin tidak menyurutkan jemaat Tunggul Wulung untuk melakukan misi. Selanjutnya Tunggul Wulung mengirim Yesaya Saritruna yang tidak lain adalah adik Benyamin sebagai penerus di Tegalombo. Kali ini dia tidak ditempatkan di Tegalombo Selatan dimana Benyamin tewas, melainkan di Tegalombo Utara (sekarang dusun Tawang Rejo). Misi kedua ini berhasil membentuk jemaat kecil sebagai cikal bakal jemaat Kristen Tawang Rejo.

\footnotetext{
${ }^{16}$ Danang Kristiawan, "Mistisisme dan Pembebasan Kyai Ibrahim Tunggul Wulung", Makalah di http://elsaonline.com/?p=1607 diakses pada 14 Februari 2015.

17Danang Kristiawan, “Mistisisme dan Pembebasan Kyai Ibrahim Tunggul Wulung”

${ }^{18}$ Wawancara dengan Sukoco, tokoh Kristen Tegalombo, dosen UKSW Salatiga, pada 31 Desember 2012.

${ }^{19}$ Danang Kristiawan "Mistisme dan Pembebasan Kyai Ibrahim Tunggul" Wulung, Makalah di http://elsaonline.com/?p=1607 diakses pada 14 Februari 2015 dan hasil wawancara dengan Sukoco pada tanggal 31 Desember 2012.

${ }^{20}$ Danang Kristiawan,"Mistisme dan Pembebasan Kyai Ibrahim Tunggul" Wulung, Makalah di http://elsaonline.com/?p=1607 diakses pada 14 Februari 2015.
}

${ }^{21}$ Soekoco dan Lawrence M. Yoder, Tata Injili di Bumi Muria, 45. 
Dalam catatan Denys Lombard, Pieter Janz adalah seorang mennonite yang menulis brosur teoretis tentang pembukaan hutan dan penginjilan (landontginning en evangelizatie), pendahulu pelbagai kelompok Kristen di daerah Muria. ${ }^{22}$ Tahun 1854 Pieter Janz bertemu Tunggul Wulung yang saat itu menyampaiakan visi tentang desa Kristen, yaitu sebuah visi untuk mengumpulkan para jemaat di sebuah tempat dengan adanya gembala di tengahtengahnya. ${ }^{23}$

Cita-cita tersebut dilanjutkan oleh P.A. Jansz, anak Pieter Jansz yang mendapatkan kepercayaan mewarisi misi Mennonit dari sang ayah. Secara definitif P.A Jansz memulai karir misonaris pada tahun 1878, saat berusia 25 tahun. P.A Jansz memulai misinya dengan mencari tempat untuk membangun cita-cita "desa Kristen". Untuk mewujudkan mimpinya, pada tanggal 3 Januari 1881 P.A Jansz mengajukan permohonan menyewa tanah dengan jangka waktu 75 tahun kepada pemerintah Belanda. Enam bulan kemudian pada 13 Agustus 1881, berdasarkan persetujuan Gubernur Jenderal dikeluarkanlah besluit atau keputusan Nomor 37 tertanggal 21 September 1882, dan kemudian disusul denga terbitnya surat Tanda Hak (akta) Nomor 5 tertanggal 13 November 1882 yang isinya menyetujui permohonan sewa tanah seluas 192 bau di Tegalombo oleh P.A Jansz. ${ }^{24}$

Setelah mendapatkan tanah sewa, rencana P.A Jansz adalah memindahkan jemaat ayahnya yang di Jepara ke desa Kristen yang akan dibangun tersebut. Sebelum memindahkan jemaat atau orang-orang yang bersedia menggarap tanah, dia telah menyiapkan suatu "peraturan persil" untuk mengatur penduduknya supaya menempuh hidup secara kekristenan. Pada tanggal 9 Juni 1883 P.A Jansz mengadakan pembukaan desa Kristen dan memberikan nama bagi persil baru tersebut dengan nama Margorejo, yang mengandung arti "jalan kepada kesejahteraan". ${ }^{25}$ Setelah pembukaan, dengan cepat dibangun rumah tinggal misionaris, bangunan sekolah misi, gereja, serta bangunan lainnya. Sekolah milik misi yang ada di sekitar Jepara kecuali di salah satu wilayah (Kedung Penjalin), dipindahkan semua di Margorejo. P.A Jansz juga membangun poliklinik pada tahun 1894 untuk pelayanan kesehatan.

Di Jawa Tengah terdapat berbagai dominasi gereja seperti Gereja Kristen Jawa Muria, Katholik, Tionghoa Muria, Bethel, Isa Al-Masih, Pentakosta dan Betania. Dari beberapa gereja tersebut, yang paling besar dan dominan ialah Gereja Jawa Muria yang lebih dulu berkembang di desa-desa sekitar lereng Muria, meliputi Pati, Kudus dan Jepara. Gerejagereja Kristen Jawa Muria yang tersebar di sekitar gunung Muria ini sekarang dikenal dengan nama Gereja Injili di Tanah Jawa (GITJ), menggantikan beberapa sebutan yang

\footnotetext{
${ }^{22}$ Denys Lombard, Nusa Jawa: Silang Budaya, Bagian I: Batas-Batas Pembaratan, Terj. Winarsih Partaningrat Arifin dkk (Jakarta: Gramedia Pustaka Utama, 2005), 101.

23Soekoco dan Lawrence M. Yoder, Tata Injil di Bumi Muria, 139.

${ }^{24}$ Soekoco dan Lawrence M. Yoder, Tata Injil di Bumi Muria, 182.

25Soekoco dan Lawrence M. Yoder, Tata Injil di Bumi Muria, 189.
} 
pernah digunakan sebelumnya. ${ }^{26}$ Para jemaat GITJ ini tersebar di karisidenan Pati yang meliputi wilayah Pati, Jepara dan Kudus atas jasa Tunggul Wulung P.A Jansz.

Dominasi GITJ juga terjadi di Tegalombo. Dari 7 gereja di Tegalombo, 4 diantaranya adalah anggota GITJ, 1 Gereja Kristen Muria Indonesia (GKMI), 1 Gereja Betania, dan 1 Gereja Pentakosta. Mengenai kelahiran Gereja Jawa Muria yang merupakan cikal bakal GITJ, menurut Soekoco mengacu pada kebaktian baptisan dan perjamuan kudus yang pertama dipimpim Piter Janz di Jepara pada tanggal 16 April 1854. Maka pada tanggal itulah selanjutnya dijadikan sebagai hari lahirnya Gereja Jawa Muria. ${ }^{27}$

Gereja Mennonit lainnya yang berada di Tegalombo adalah Gereja Kristen Muria Indonesia (GKMI) yang lahir pada 6 Desember 1920 di Kudus. Nama Gereja diambil dari nama gunung (Gunung Muria) yang terletak di daerah Jawa Tengah bagian Utara. Gereja lainnya adalah Pantekosta yang berada tidak jauh dari GITJ Margorejo. Gereja ini merupakan salah satu lembaga gereja Kristen Protestan di Indonesia. Tahun 1923 ditengarai sebagai awal berdirinya Gereja Pentakosta di Indonesia atas inisiasi F.G Van Gesse, seorang misonaris Belanda yang melakukan pelayanan di Cepu, Jawa Tengah..$^{28}$

Dalam perkembangannya umat Islam Tegalombo merespon perkembangan Kristen disana. Ada dua hal yang menjadi tanda kebangkitan Islam di Tegalombo yaitu adanya penguatan ajaran keislaman dan munculnya organisasi dan lembaga berbasis Islam. Kedua tanda kebangkitan Islam ini dapat dilihat dari tumbuh kembangnya penyiaran Islam melalui lembaga pendidikan Islam seperti pesantren dan madrasah.

Madarijul Huda merupakan pesantren pertama di kecamatan Dukuhseti yang didirikan pada tahun 1947 oleh kyai kharismatik KH. Hasbullah. Menurut Kyai Muzayyin, pimpinan Yayasan Madarijul Huda saat ini, pendirian pesantren Madarijul Huda bertujuan untuk memperkuat pendidikan Islam bagi anak-anak di Kembang dan desa-desa sekitar seperti Tegalombo, Puncel, Groglan serta Banyutowo. ${ }^{29}$

Kehadiran Madarijul Huda pimpinan KH. Hasbullah turut memengaruhi tumbuh kembang umat Islam Tegalombo. Sejak kehadiran desa Persil di bawah pimpinan P.A Jansz, umat Islam Tegalombo khawatir dengan meningkatnya jumlah pemeluk Kristen di dusun Margorejo. Hadirnya pesantren Madarijul Huda setidaknya mengurangi kekhawatiran sejumlah kyai akan pindahnya sebagian umat Islam terutama dari abangan ke agama

\footnotetext{
26Soekoco dan Lawrence M. Yoder, Tata Injil di Bumi Muria, 8.

${ }^{27}$ Soekoco dan Lawrence M. Yoder, Tata Injil di Bumi Muria, 8.

${ }^{28}$ Baca "Sejarah GPDI" dalam http://gpdi.or.id/index.php/profil/sejarah-gpdi, diakses pada tanggal 4 Februari 2015.

${ }^{29}$ Wawancara dengan KH. Muzayyin, ketua yayasan Madarijul Huda pada tanggal 2 Januari 2012 di desa Kembang, kecamatan Dukuhseti.
} 
Kristen, karena kebanyakan pemuda di Tegalombo saat itu dapat menimba pengetahuan agama Islam di Pesantren Madarijul yang dekat dengan desa mereka. ${ }^{30}$

Dalam perkembangannya, santri-santri Tegalombo mulai berfikir untuk mengembangkan pendidikan Islam model madrasah di desa sendiri. Dengan dukungan Pesantren dan Madrasah Madarijul Huda Kembang, pada tahun 1985 berdiri Madrasah Ibtidaiyah Minsyaul Huda yang terletak di dusun Krajan. Berdirinya madrasah ini bertujuan untuk menyebarkan dan mengamalkan ajaran agama Islam serta mewujudkan dan meningkatkan pendidikan Islam. Selain melaui peran madrasah, para santri juga mulai memperkuat peran masjid sebagai pusat pengembangan dakwah Islam. Pada awal berdirinya, tenaga guru atau pengajar adalah santri-santri alumni dan guru dari Madarijul Huda. Namun pada perkembangannya banyak guru dari luar Tegalombo dan Kembang juga mengajar di MI tersebut.

Pada tahun 1993, MI dan Masjid Jami' Tegalombo menjadi satu yayasan yang bernama Yayasan al-Fatah Di bawah Yayasan ini, perkembangan MI cukup pesat dimana muridmuridnya tidak hanya dari Tegalombo melainkan dari beberapa desa tetangga seperti Grogolan dan Puncel. Data saat ini, menunjukkan bahwa murid MI berjumlah 247 dengan 17 guru dan karyawan. Bagi murid yang sudah lulus MI, kebanyakan dari mereka melanjutkan ke jenjang Tanawiyah dan kemudian Aliyah di madrasah Madarijul Huda atau Manhajul Huda di desa Ngagel. ${ }^{31}$

Pada tahun 1995 Muslimat NU (salah satu organisasi perempuan badan otonom di tubuh NU) Tegalombo yang diketuai ibu Maryati dengan dukunganYayasan Al-Fatah menginisiasi berdirinya TPQ Nurul Fatah. TPQ ini memberikan pengajaran baca tulis alQur'an bagi anak-anak berusia sekolah dasar (6-12 tahun). Menurut Ibu Maryati, hadirnya TPQ ini bertujuan menyiapkan anak didik agar menjadi generasi muda yang Qur'ani. ${ }^{32}$ Saat ini, selain Nurul Fatah juga berdiri TPQ Al-Ikhlas di dusun Tawangrejo yang juga dikelola oleh Muslimat NU. Meskipun telah tersedia TPQ, namun masih ditemukan banyak anak-anak yang mengaji dengan bimbingan guru ngaji di beberapa mushola.

Di Tegalombo terdapat dua masjid Jami' yaitu Masjid Al Fatah di Krajan dan Sabilul Huda di Tawang Rejo. Masjid Al-Fatah berdiri pada tahun 1978 yang diinisiasi Solikhin Jupri, yang saat itu menjabat ketua NU ranting Tegalombo. Masjid yang terletak di pinggir jalan raya Tayu-Puncel ini berdiri sekitar 100 meter dari GITJ Tegalombo. Di kompleks masjid ini juga terdapat MI Minsyaul Huda dan TPA Nurul Fatah. Selain Al Fatah, pada tahun 1985,

\footnotetext{
${ }^{30}$ Wawancara dengan KH. Muzayyin, pada tanggal 2 Januari 2012 di Pesantren Madarijul Huda desa Kembang

${ }^{31}$ Wawancara dengan Solikhin Jupri pada tanggal 23 Maret 2012 di Tegalombo.

${ }^{32}$ Wawancara dengan Maryati, pengurus Muslimat NU Tegalombo pada tanggal 1 Januari 2013 di Tegalombo.. Maryati adalah menantu Kasah, kepala desa Tegalombo periode 1966-1978. Selain aktif di Muslimat NU, ia juga aktif mengisi pengajian rutin di Majlis Taklim di Krajan dan Tawang Rejo.
} 
Solihin Jupri juga turut berjasa dalam pendirian Masjid Sabilul Huda dusun Tawang Rejo. Di kedua masjid tersebut Solihin Jupri menjadi tokoh sentral, selain menjadi khotib Jumat juga menjadi dewan pembina Takmir.

Masjid AL-Fatah dan Sabilul Huda menjadi pusat untuk memperkuat pemahaman dan pengamalan ajaran agama Islam. Salah satu kegiatan rutin masjid tersebut adalah ibadah pengajaran al-Qur'an, pengajian yasinan setiap Kamis malam sehabis Maghrib, dan pembacaan al-barjanji setiap Kamis malam setelah shalat Isya'. ${ }^{33}$ Kegiatan rutin tahunan yang dikelola Takmir Masjid adalah pengelolaan zakat fitrah, serta Peringatan Hari besar Islam (PHBI) seperti isra' mi'raj, maulidan dan rajaban. Untuk mengelola peribadatan dan kegiatan sosial- keagamaan tersebut menjadi tanggung jawab Takmir Masjid yang diisi oleh para individu yang dianggap mumpuni dalam ilmu agama dan sebagian lagi karena dianggap mampu mengemban tugas pelayanan umat.

Umat Islam tegalombo melakukan aktualisasi keagamaan melalui organisasi atau kelompok keagamaan seperti Nahdlatul Ulama (NU), Majlis Taklim dan bahkan ada kelompok kebatinan (ziarah kubur). NU merupakan organisasi Muslim tradisionalis yang didirikan di Surabaya pada tahun 1926 atas inisiasi ulama kharismatik seperti Hasyim Asy'ari dan Wahab Hasbullah. ${ }^{34}$ NU sendiri masuk di Tegalombo pada dekade pertengahan 80-an. Fokus dan strategi gerakan organisasi ini adalah pada penerapan Islam substantif dan akomodasi budaya lokal. Perhatian utama dakwah NU adalah penguatan tauhid atau keesaan Tuhan.

\section{Kontestasi dan Ketegangan}

Setelah peristiwa terbunuhnya misonaris Benyamin Djojotruno pada 1878, ada tiga peristiwa yang menimbulkan ketegangan hubungan antara kelompok Islam dan Kristen di Tegalombo. Ketiga peristiwa tersebut adalah pembakaran gereja Margorejo tahun 1942, Pengajian Akbar tahun 1996 dan KKR tahun 2009.

Tidak banyak masyarakat Tegalombo yang mengetahui peristiwa rayahan tahun 1942 yang berbuntut pada memburuknya relasi Islam dengan Kristen. Namun bagi para Pendeta di Tegalombo sejarah kelam tersebut tersimpan dalam memori dan buku Tata Injil di Bumi Muria yang ditulis Sukoco (dosen di Universitas Satya Wacana Salatiga kelahiran Tegalombo tahun 1950) dan Lawrence M. Yodar (teolog dari Amerika yang pernah mengajar di Akademi Kristen Wiyata Wacana Pati pada tahun 1979).

Dalam wawancara dengan Suharto, pendeta GITJ Margorejo, penulis mendapati narasi yang sangat detail, sesuai dengan catatan dalam buku. Dalam buku tersebut dituliskan awal mula serangan ke Margorejo yang diawali dari wilayah Tayu; "dari antara tempat yang lain

\footnotetext{
${ }^{33}$ Wawancara dengan Sholih, pengurus Takmir Masjid Sabilul Huda, pada tanggal 1 Januari 2012 di Tawang Rejo.

${ }^{34}$ Djohan Effendi, Pembaharuan Tanpa Membongkar Tradisi: Wacana Keagamaan di Kalangan Generasi Muda NU Masa Kepemimpinan Gus Dur (Jakarta: Penerbit Buku Kompas, 2010), 84.
} 
di sekitar Muria, Tayu mendapat perhatian pertama untuk merasakan serbuan massa yang digerakkan Ansor atau Islamiyah tersebut. Sejak hari Selasa, 3 Maret massa sudah mulai menyerbu sasaran. Peristiwa ini biasanya terkenal sebagai "jaman rayahan". ${ }^{35}$ Dari Tayu, gerakan Ansor kemudian mengarah ke Margorejo, sebagaiamana yang ditulis sebegai berikut;

\begin{abstract}
"Dari Tayu, gerakan Ansor menuju Utara dengan mengambil basis di Ngagel lebih kurang lima kilometer di utara Tayu. Tujuannya sudah jelas yaitu jemaat-jemaat Kristen Margorejo dan sekitarnya. Dengan menyeret masa, gerakan Ansor bergerak ke Margorejo pada hariu Minggu 8 Maret 1942. Sebelum masa rakyat dan Ansor sampai di Margorejo sebetulnya orang-orang Tionghoa yang tinggal di Margorejo sudah dirayah masa setempat, sejak 28 Februari bahkan ada sebagaian orang Kristen yang ikut serta dalam rayahan tersebut. Dengan demikian tujuan Ansor ke Margorejo semata-mata bermaksud mengambil sasaran jemaat-jemaat Kristen Margorejo. Beberapa pemimpin Margorejo telah meninggalkan rumahnya untuk mengungsi seperti yang diperbuat oleh penduduk, kecuali bekas Pendeta Roeben Martorejo dan Pendeta S. Harsosoedirdjo keduanya di Margorejo serta guru Injil sekaligus ketua Majlis Gereja Samoel Saritroeno yang berada di Tegalombo" ${ }^{36}$
\end{abstract}

Gereja Margorejo yang mewah yang dinding-dindingnya hasil karya pengukir-pengukir kayu dari Jepara itu seketika habis terbakar. Akibat peristiwa itu para jemaat banyak yang melarikan diri dengan rasa takut dan kecemasan. Bisa dikatakan saat itu Margorejo telah hancur baik segi jasmani maupun rohaninya. ${ }^{37}$

Peristiwa kedua adalah terkait pengajian Isra' Mi'raj tahun 1996 yang diundang mengundang seorang mantan pendeta yang kini memeluk agama Islam sebagi da'i. . Saat pengajian berlangsung sang da'i berkisah tentang pengalaman spiritualnya akan pencarian agama. Muhafidz, yang saat itu hadir dalam pengajian memberikan kesaksian bahwa sang da'i bercerita bahwa suatu malam ia bermimpi bahwa patung Yesus yang disalib, simbol Tuhan yang disembah dan disanjung sehari semalam, pada suatu hari jatuh menyebabkan tangan sebelah kanannya retak. Akhirnya sang pendeta berfikir kenapa Tuhan selemah itu, yang kemudian membuat hatinya gamang. Lalu ia coba mendekati kawan-kawan yang Islam, dan mencoba mencari tahu tentang Islam yang pada akhirnya ajaran Islam banyak memberikannya ketenangan. ${ }^{38}$

Meskipun tidak sampai pada pembubaran atau protes saat berlangsungnya acara, namun peristiwa tersebut mengusik warga Kristen yang menghuni Tawang Rejo khusunya. Mengingat pemukiman warga Kristen dan Muslim di Tawang Rejo membaur maka isi ceramah dari mushola di tengah pemukiman juga jelas terdengar oleh warga Kristen. Kurang lebih sebulan setelah persitiwa itu ketegangan tersebut berhasil diredam melalui forum Selapanan. Beberapa tokoh Kristen yang hadir menyampaikan keberatannya atas pengajian tersebut. Salah satunya adalah Sudadi, guru Injil yang menilai bahwa hadirnya

\footnotetext{
${ }^{35}$ Soekoco danLawrence M. Yoder, Tata Injil di Bumi Muria, 310

36Soekoco dan Lawrence M. Yoder, Tata Injil di Bumi Muria, 313-314.

${ }^{37}$ Soekoco dan Lawrence M. Yoder, Tata Injil di Bumi Muria, 319.

${ }^{38}$ Hasil wawancara dengan Muhafidz, modin atau Kaur Kesra Tegalombo, pada tanggal 23 Mei 201.
} 
mantan pendeta dalam pengajian kurang memperhatikan etika hubungan antar umat beragama. Maka, dalam kesempatan tersebut, dari tokoh-tokoh Islam seperti Muhafidz dan Sholeh meminta maaf dan berkomitmen untuk tidak mengulangi lagi pengajian yang menyinggung umat Kristen. Dalam kesaksian Suyatno, dalam pembahasan tersebut kedua tokoh saling memaafkan dan menganggap yang sudah terjadi menjadi pelajaran berharga dalam merawat kerukunan. ${ }^{39}$

Peristiwa ketiga adalah kegiatan Kebaktian Kebangunan Rohani (KKR) tahun 2009. KKR yang diadakan pengurus GITJ Margorejo terakhir kali diselenggarakan pada tahun 2008. Sepanjang sejarah penyelanggarannya, KKR tahun tersebut adalah yang paling besar diantara KKR sebelumnya, yang dihadiri lebih dari sepuluh ribu jemaat sinode GITJ (Gereja Injili Tanah Jawa) se kabupaten Pati. Kegiatan KKR tersebut berlangsung aman dan tanpa menimbulkan ketegangan dengan masyarakat Muslim, seperti pada pelaksanaan sebelum-sebelumnya. ${ }^{40}$ Setahun berikutnya, pada tahun 2009 kembali digelar KKR di Margorejo (14-16 September) yang menimbulkan ketegangan relasi Kristen dengan Islam. Pada KKR kali ini, sebagai panitia adalah seorang jemaat dari GITJ Tawang Rejo.

Awalnya, panitia penyelanggara datang ke Margorejo mengenai maksud kegiatan tersebut. Pengurus gereja Margorejo menyatakan kesediannya bekerjasama dengan mengajukan beberapa syarat. Pertama, Pengurus gereja Margorejo meminta dipertemukan dengan narasumber KKR, untuk memastikan bahwa tujuan dari kegiatan KKR tersebut hanyalah untuk penguatan keimanan umat Kristen. Kedua, penyelanggara harus transparan mengenai agenda dengan tidak mengadakan kegiatan yang memancing isu kristenisasi. Ketiga, penyelenggara terlebih dahulu harus melakukan audiensi dengan multipihak, baik dari pemerintah maupun tokoh-tokoh agama untuk mendapatkan ijin, sebagaimana prosedur yang dipegang gereja Margorejo selama ini.

Meskipun tanpa dukungan gereja Margorejo dan ijin penyelenggaraan, panitia penyelenggara tetap menjalankan rencana KKR di lapangan desa, persis depan gereja Margorejo, yang sebelumnya digunakan untuk KKR tahun 2008. Sebulan sebelum pelaksanaan KKR sudah mendapat reaksi dari kalangan tokoh-tokoh Islam yang bukan berasal dari Tegalombo, melainkan dari desa-desa yang terkenal kuat basis Islamnya di sekitar Tegalombo, seperti Dukuhseti, Kembang dan Ngagel. Para tokoh tersebut mendatangi panitia penyelanggara di Tawang Rejo, karena tersinggung dengan iklan KKR yang terkesan mengundang warga lain (Islam) untuk hadir. Mereka mennyangkan tindakan panitia yang mengumumkan KKR dengan mobil berkeliling sembari menyebar pamflet berisi pengobatan gratis dan pembagian sembako.

\footnotetext{
${ }^{39}$ Hasil wawancara dengan Suyatno, salah satu tokoh pemuda Islam Tawang Rejo yang hadir dalam forum Selapanan membahas rekonsiliasi paska pengajian pada 31 Desember 2012.

40Wawancara dengan Suharto, Pendeta GITJ Margorejo pada tanggal 31 Desember 2012.
} 
Dalam pandangan tokoh-tokoh Islam, tindakan tersebut sama saja dengan memberikan undangan kepada umat Islam, sehingga menyalahi prosedur selama ini dimana KKR tertutup untuk yang bukan Kristen. Reaksi keras tersebut juga ditunjukkan munculnya spanduk-spanduk yang berisi kewaspadaan terhadap kristenisasi yang terpajang di beberapa ruas jalan raya Tayu-Puncel, yang menghubungkan dengan desa Tegalombo. ${ }^{41}$

Meskipun mendapat persoalan perijinan dan juga reaksi keras masyarakat Muslim dari desa lain, akhirnya KKR pun tetap berjalan dengan berbagai perubahan acara. Acara yang berlangsung selama 3 hari ini dimulai dengan kegiatan pengobatan gratis untuk umum yang ditangani oleh dokter-dokter dari Yogyakarta. Ini berbeda dengan cara KKR sebelumnya yang menggunakan metode do'a penyembuhan ilahi. Hari kedua panitia memberikan sembako gratis kepada masyarakat dusun Margorejo. Hal ini tentu diluar ekspektasi panitia yang semula merencanakan membagikan ribuan paket untuk warga Tegalombo dan juga warga desa sekitar. Hari terakhir, acara diisi dengan ibadah atau pujian, konser menyanyi yang dilanjutkan dengan ceramah oleh narasumber dari Kanada. ${ }^{42}$

Selain beberapa kasus di atas, konversi agama juga turut menyebabkan ketegangan antar kedua kelompok agama ini. Situasi paska tahu 1965, terjadi konversi besar-besaran bekas anggota PKI (Partai Komunis Indonesia) dan dan Islam abangan ke dalam agama Kristen. Di laporkan dalam kurun 1965-1971 sekitar 2.000.000 (dua juta) Muslim Jawa telah dibaptis menjadi Kristen. ${ }^{43}$ Di Tegalombo sendiri, banyak kaum abangan yang berpindah menjadi Kristen untuk alasan menyelematkan diri dari kejaran penculikan pembunuhan. Proses konversi tersebut berlangsung sangat cepat dan dramatis. Waktu itu masyarakat dianjurkan untuk berkumpul di rumah pendeta (Kristen) atau kyai (Islam), sebagai wujud simbolik identitas agama yang dianutnya. Dari informasi berbagai narasumber menyebutkan lebih dari 30\% umat Islam saat itu di Tegalombo (dusun Krajan dan Tawang Rejo) berpindah agama menjadi Kristen.

Dengan berbagai pertimbangan, kaum abangan lebih memilih untuk berkumpul atau bersembunyi di rumah sang pendeta. Hal tersebut seperti yang diceritakan ibu Rasyidah, warga Muslim Tawang Rejo yang menyaksikan sendiri peristiwa itu. Saat maraknya peristiwa pemumpasan PKI, ia baru saja menikah dan pindah ke Tegalombo, desa suaminya. Bersama suami, keluarga dan warga lainnya ia ikut-ikutan saja berlindung ke rumah Kyai Thalib. Ia menyaksikan para tetangga yang Kristen juga berlindung, tetapi di rumah pendeta Latip. Menurut pengakuannya, tetangga yang Islam-nya 'KTP' (abangan) sebagian ikut ke Kyai, dan sebagian lainnya ke rumah pendeta Latip. Menurutnya, saat

\footnotetext{
41Wawancara dengan Djamhuri, jamaah Masjid Sabilul Huda, pada tanggal 1 Januari 2011.

42Wawancara dengan Suharto, Pendeta Gereja Margorejo, pada tanggal 31 Desember 2011.

${ }^{43}$ Azyumardi Azra, Konteks Berteologi di Indonesia, 60.
} 
peristiwa itu terjadi ia dan Muslim lainnya tidak sempat melarang mereka (Islam KTP) untuk ikut pendeta Latip, karena yang terpenting saat itu adalah mencari perlindungan. ${ }^{44}$

Monografi Desa Tegalombo menyebutkan bahwa pada tahun 2012 jumlah penduduknya mencapai 5969 jiwa, dimana 71,9\% (4294 jiwa) adalah beragama Kristen, dan selebihnya 28,1 \% (1675 jiwa) beragama Islam. ${ }^{45}$ Dusun Margerejo identik dengan desa Kristen karena menjadi desa persil_pusat kegiatan agama Kristen sejak pertama kali Kristen masuk di wilayah ini pada akhir tahun 1880-an. Pada tahun 2012, dari total 1974 jiwa, umat Muslim hanya berjumlah $10 \mathrm{KK}$ (Kepala Keluarga) dengan 52 jiwa (2,6\%). Di dusun Krajan yang penduduknya berjumlah 2014 terdiri dari 827 beragama Islam dan 1185 beragama Kristen. Krajan sendiri masih terbagai dalam wilayah kecil seperti Punggur, Kernen dan Jrakah Landak. Dusun terakhir adalah Tawang Rejo, yang terletak di ujung pesisir laut desa. Dusun ini komposisi Kristen dan Islamnya adalah 796 (40,1\%) Islam dan 1185 (58,9\%) Kristen.

Selanjutnya data tersebut dapat dilihat dalam tabel berikut: Migrasi yang terjadi di Tegalombo adalah sebagaimana wilayah lain yaitu adanya pendatang yang merupakan menantu, dan orang yang pergi ke luar desa karena perkawinan maupun menjadi perantau. Menurut Edi Santoso, Kepala Desa Tegalombo, kebanyakan warganya merantau di Lampung sebagai petani tambak dan petani hutan yang jika dikalkulasi jumlahnya ada sekitar 200 orang. Dari total tersebut, hanya ada sekitar 25 orang yang pindah menjadi warga desa setempat di Lampung. Selebihnya masih menjadi warga Tegalombo, yang biasanya setahun sekali pulang kampung untuk merayakan Natal atau Idul Fitri. ${ }^{46}$

Dari pengalaman konflik antara kelompok Islam dan Kristen di Tegalombo, kecurigaan terhadap aktivitas dakwah atau misi merupakan akar utama konflik. Ketika kecurigaan ini menguat, maka potensi konflik terbuka bisa saja terjadi. Konflik atas penyelenggaraan pengajian Akbar dan KKR memang tidak sampai pada konflik horizontal yang mengarah pada kekerasan, namun menyebabkan renggangnya relasi sosial keduanya. Protes tokohtokoh Kristen atas penyelenggaraan pengajian Akbar dan protes ulama Islam atas kegiatan KKR jika dicermati faktor penyebabnya bukanlah karena perbedaan doktrin teologis, namun lebih kuat karena konteks sosiologis yang memicunya.

Faktor sosial yang memicu konflik dalam kasus Pengajian Akbar 1996 dan KKR 2009 tersebut salah satunya sangat kuat dipicu masih adanya sentimen keagamaan yang ditandai dengan adanya rasa saling curiga, dan juga stereotype antar kelompok. Hal ini senada dengan Koentjaraningrat yang menyebut bahwa terjadinya suatu konflik karena adanya kecurigaan dalam interaksi sosial. Rasa curiga tersebut bisa disebabkan oleh adanya

\footnotetext{
${ }^{44}$ Wawancara dengan Rosyidah (72 tahun), perempuan Muslim, pada tanggal 31 Desember 2011 di rumahnya di Dusun Tawang Rejo, Tegalombo.

${ }^{45}$ Laporan Monografi desa Tegalombo pada tahun 2012.

${ }^{46}$ Wawancara dengan Edi Santoso, Kepala Desa Tegalombo pada tanggal 3 Januari 2012 di kantor Balai Desa Tegalombo.
} 
pandangan tidak wajar atas golongan lain, atau stereotype negatif terhadap kelompok lain. Namun yang perlu dicatat disini adalah bahwa sentimen tersebut berangkat dari beberapa tokoh agama dan beberapa anggota jemaah masing-masing. Bahkan untuk kasus KKR, sentimen justru muncul dari tokoh dan kelompok Islam di luar desa Tegalombo.

Sentimen ini kemudian melahirkan sebuah sikap dan persepsi negatif kepada pihak lain yang bisa mengarah pada meluasnya eskalasi konflik. Semula sikap curiga muncul dalam diri tokoh-tokoh agama, lalu menyebar kepada para pengikutnya dan masyarakat. Bentuk eskalasi konflik ini adalah melihat pihak lawan sebagai pihak yang tidak bermoral, kurang dapat dipercaya, kurang ramah, atau senang bermusuhan. ${ }^{47}$ Ketika dalam situasi konflik, dua kelompok dalam masyarakat seringkali sulit untuk tetap bersifat netral. Alasanya adalah para aktor dalam konflik cenderung mencari dukungan para anggota dari asal kelompoknya.

Konversi agama, dalam perkembangannya menyebabkan sikap waspada diantara kelompok agama sendiri. Meskipun saat ini kebanyakan melalui jalur perkawinan, akan tetapi isu ini tetap menjadika agama dalam posisi dikompetisikan. Garry D. Bouma menyebut bahwa kompetisi agama tersebut bisa juga disebabkan perbedaan agama dan juga praktek keagamaan sebuah kelompok yang mensikapi peningkatan jumlah pemeluk agama tertentu. ${ }^{48}$

Selain faktor sentimen keagamaan, faktor selanjutnya yang turut memicu konflik adalah pengabaian aturan terkait penyiaran agama antar kedua kelompok. Dalam prakteknya, penyiaran agama sendiri memiliki dua sisi posisi yang berbeda. Di satu sisi, penyiaran agama dapat memicu terjadinya gangguan pada kerukunan, bahkan memicu terjadinya konflik. Sisi lain, penyiaran agama juga bisa menimbulkan kesejukan, kedamaian dan memelihara kerukunan umat beragama jika dilakukan dengan mengindahkan etika kerukunan.

Dalam KKR 2009, tokoh Muslim memandang terjadinya pelanggaran kesepakatan syiar agama dengan menyebarkan informsi melalui pengeras suara, berkeliling dengan mobil sembari menyebarkan selebaran ke kelompok Islam. Tentu saja, reaksi muncul dari kelompok Islam dari desa tetangga, yaitu Kembang. Merespon hal ini beberapa tokoh Islam di tegalombo juga turut menyayangkan hal ini. Setali tiga uang, akhirnya tokoh Islam Kembang dan Tegalombo yang berbasis di Tawang Rejo meminta pertanggung jawaban panitia yang telah mengabaikan aturan syiar agama tersebut.

Dari semua faktor yang telah disebutkan, kemungkinan faktor lain bisa dicermati dari pandangan Clifford Geertz yang menyatakan ada empat faktor yang mempertajam

${ }^{47}$ Dean G. Pruitt dan Jeffrey Z. Rubin, Teori Konflik Sosial, terj. Helly P. Sutjipto dan Sri Mulyati (Yogyakarta: Pustaka Pelajar, 2004), 211.

${ }^{48}$ Garry D. Bouma, "The Challenge of Religious Revitalization and Religious Diversity", dalam Briyan S. Turner (Ed.), Religious Diversity and Civil Society (Oxford: The Bardwell Press, 2008), 181. 
konflik. ${ }^{49}$ Pertama, konflik ideologis yang mendasar, karena rasa tidak senang, terhadap nilai-nilai kelompok lain. Kedua, sistem stratifikasi sosial yang berubah dan mobilitas status yang cenderung untuk memaksakan adanya kontak diantara individu-individu dan kelompok-kelompok yang secara sosial dulu sedikit banyak terpisah. Ketiga, perjuangan mencapai kekuasaan politik yang semakin tajam untuk mengisi kekosongan yang ditinggalkan oleh pemerintah kolonial yang cenderung mencapur adukkan kepentingan agama dengan kepentingan politik. Keempat, kebutuhan mencari kambing hitam untuk memusatkan ketegangan akibat perubahan sosial yang cepat.

Kejadian dalam rencana penyelangaraan KKR pada tahun 2009 di atas dapat menjadi contoh bagaimana konflik merambah sampai ke luar desa Tegalombo, tanpa mekanisme penyelesaian dari internal Tegalombo. Menguatnya ketegangan keduanya akhirnya memaksa Pemerintah Daerah (Pemda) Kabupaten Pati harus turun tangan untuk menyelesaikannya dengan menggelar musyawarah antar agama pada tanggal 2 September 2009. Hadir dalam musyawarah tersebut dari unsur pemerintah (Depag, Muspida, Polres), tokoh agama Islam (Nahdlatul Ulama), dan tokoh Kristen (diwakili oleh Sinode). Selain itu beberapa tokoh agama dan pemuda dari Tegalombo juga dihadirkan untuk memberikan kesaksian sekaligus dengan harapan akan membawa informasi yang bersifat meredakan ketegangan.

Musyawarah ini bertujuan untuk mengurangi ketegangan yang terjadi menjelang KKR di Tegalombo. Respon pemerintah tersebut bisa dibilang terlambat karena eskalasi konflik sudah meluas tidak hanya di desa Tegalombo namun di tingkat kecamatan Dukuhseti. Menurut Suyatno, pemuda Islam Tawang Rejo yang ikut dalam dialog menuturkan bahwa setidaknya dengan dialog ini beberapa kesepakatan diambil agar konflik ketegangan tidak menjadi konflik terbuka atau mengarah tindakan kekerasan. Diantara hasil kesepakatan tersebut adalah tetap diijinkannya penyelenggaraan KKR 2009 dengan mempertimbangkan beberapa hal yang menjadi keberatan warga Muslim. ${ }^{50}$ Pertama, terkait kupon sembako yang rencananya dibagikan saat KKR hanya diperuntukkan terbatas bagi umat Kristen di Margerojo saja. Pada mulanya kupon dibagikan panitia ke masyarakat wilayah sekitar Tegalombo baik yang beragama Kristen maupun Islam. Kedua, untuk acara ibadah yang semula direncanakan diselenggarakan di lapangan halaman gereja, diganti di dalam gereja. Namun untuk acara hiburan dan pengobatan ilahi dapat dilakukan di lapangan.

Kedua belah pihak dalam musyawarah tersebut berjanji untuk menghormati kesepakatan tersebut. Hal tersebut dapat dilihat dari berjalannya acara KKR selama tiga hari. Terselenggaranya dialog atau musyawarah tersebut didukung oleh beberapa faktor. Pertama, faktor ideologi Pancasila yang mendorong munculnya budaya musyawarah di kalangan masyarakat Indonesia. Kedua, Sistem politik yang demokratis sangat mendukung perkembangan budaya dialog, karena demokrasi mengandaikan penyelesaian konflik tanpa

${ }^{49}$ Clifford Geertz, Agama di Jawa; Konflik dan Integrasi, dalam Roland Robertson (ed), Agama: Dalam Analisa dan Intepretasi Sosiologi, (Terj.) Acmad Fedyani Syaifuddin (Jakarta: CV Rajawali, 1988), 207.

${ }^{50}$ Wawancara pada tanggal 31 Desember 2011 di rumahnya di dusun Tawang Rejo, Tegalombo. 
kekerasan. Ketiga adalah nilai ajaran agama, yang menganjurkan umat beragama untuk menggunakan cara bijak dalam penyelesaian persoalan. Islam misalnya, sangat mengutamakan musyawarah dalam menyelesaikan masalah sehingga menyuburkan budaya dialog.

\section{Relasi Damai Islam-Kristen}

B.J. Boland menegaskan bahwa tidak pernah terjadi di manapun di lingkungan dunia Islam (mungkin dengan pengecualian di Indonesia) kaum Muslim merasa bahwa rekan senegaranya yang bukan beragama Islam adalah 'salah seorang dari kita." 51 Pernyataan ini menyiratkan esensi kerukunan antar umat beragama, yang merupakan satu kesatuan dan hidup dalam koeksistensi damai (peaceful co-existence).

Fenomena budaya di Tegalombo dapat dicermati dari upacara siklus kehidupan, perayaan hari besar keagamaan, kegiatan sosial kemasyarakatan serta relasi dalam pekerjaan. Dalam siklus yang melingkari kehidupan diantaranya juga terdapat ritus perkawinan yang dalam budaya Jawa dirayakan dengan upacara atau pesta sebagai bentuk ucapan syukur kepada Tuhan. Pertama, kelahiran. Upacara kelahiran sendiri dimulai sejak bayi dalam kandungan yang dikenal dengan tradisi mitoni (7 bulan kehamilan). Modin atau pendeta membuka acara dengan menyampaikan ucapan terima kasih kepada undangan dan ucapan syukur atas calon anak yang dikandung ibunya. Pengantar yang disampaikan modin saat memimpin acara mitoni adalah sebagai berikut: "saudara-saudara semua para tamu undangan, khususnya para sesepuh yang kami hormati, saya bicara atas nama keluarga (menyebutkan nama keluarga pasangan suami-istri) bermaksud menyampaikan hajat kami hari ini yaitu mengharap keselamatan kepada Allah, agar ibu dan bayi yang dikandung dalam keadaan sehat dan nantinya dapat lahir tanpa halangan apapun." 52

Setelah pengantar singkat dilanjutkan dengan do'a meminta keselamatan pada si bayi agar sehat dalam kandungan dan lahir dengan selamat. Dalam kesempatan ini, pendeta ataupun modin mengajak undangan yang bukan seagama dengan pemilik hajat, untuk juga turut mendo'akan sesuai keyakinan masing-masing. Kedua, upacara perkawinan. Dalam prosesi resepsi jika yang mempunyai hajat adalah keluarga Kristen, warga Muslim juga hadir sebagai undangan. Biasanya dalam resepsi disertai do'a terhadap pengantin, sehingga sang pendeta meminta ijin untuk berdo'a sesuai ajaran Kristen untuk menghormati undangan yang Muslim. Ucapan ijin dan permohonan doa tersebut adalah, "nyuwun kamardikan manahipun, ndedungo kanti kapercadosanipun piyambak-piyambak/ mohon dengan hormat untuk berdo'a sesuai kepercayaan masing-masing. "53

\footnotetext{
${ }^{51}$ B. J. Boland, Pergumulan Islam di Indonesia 1945-1970, Terj. Saafroedin Bahar (Jakarta: Grafiti Pers, 1985), 234.

52Wawancara dengan Muhafidz pada tanggal 24 Mei 2012.

53Wawancara dengan Suharto, pendeta GITJ Margorejo pada tanggal 20 Juli 2012 di rumahnya di dusun Margorejo, Tegalombo.
} 
Ketiga, upacara kematian. Jika salah seorang warga Tegalombo meninggal, baik Kristen ataupun Islam, akan menjadi duka bersama. Para pemuda berkumpul di makam untuk menggali kubur dan mempersiapkan kebutuhan upacara pemakaman lainnya. Sementara yang lainnya, dari kalangan bapak dan ibu melayat ke rumah duka. Pelayat baik yang di rumah maupun di tempat pemakaman juga turut menyaksikan prosesi atau ritual upacaranya. Dalam upacara kematian, anggota kelompok dari Islam maupun Kristen umumnya mengetahui kegiatan apa saja yang boleh dilakukan oleh pihak lain dan kegiatan mana yang hanya dapat dilakukan sendiri oleh sesama kelompoknya.

Silaturahmi Natalan yang jatuh pada setiap tanggal pertama tahun baru Masehi (1 Januari) itu tidak hanya dilakukan oleh umat Kristen, tetapi juga melibatkan umat Islam. Oleh karenanya, mengingat tradisi saling kunjung ini mirip tradisi bodo Syawal, maka masyarakat Tegalombo juga menyebut Natalan sebagai bodo Natal. Adapun yang diucapkan baik Kristen maupun Muslim ketika bertamu dan berjabat tangan adalah, sugeng warsa enggal, ngapurone sedoyo lepat kawula (selamat tahun baru, maafkan segala kesalahan saya). Saat Syawal tiba, umat Muslim berkunjung kepada saudara, kerabat maupun tetangga yang Muslim untuk saling meminta maaf. Pada hari kedua lebaran, barulah saudara, kerabat maupun tetangga atau rekan dan teman yang Kristen berkujung ke rumah-rumah orang Muslim. Dipilihnya hari kedua lebaran ini dimaksudkan untuk memberikan kesempatan sesama umat Muslim terlebih dahulu untuk bersilaturahmi. ${ }^{54}$

Kegiatan sosial-kemasyarakatan yang menjadi media memperkuat integrasi Islam-Kristen di Tegalombo diantaranya adalah ruwatan desa atau sedekah bumi dan peringatan Pitulasan (17-an). Sedekah bumi merupakan upacara syukur masyarakat desa atas hasil panen atau hasil bumi, yang masih langgeng hingga zaman sekarang. Nilai penting sedekah bumi adalah do'a yang oleh seorang fenomolog agama Freiderich Heiler dikatakan bahwa orang-orang beragama, pengkaji agama, para teolog semua kepercayaan dan kecenderungan, sepakat dalam berpendapat bahwa do'a adalah fenomena utama seluruh agama dan menjadi jantungnya agama. ${ }^{55}$ Oleh karenanya, do'a bersama ini menarik untuk diperhatikan untuk melihat sejauh mana pandangan umat beragama terhadap do'a antar umat beragama. ${ }^{56}$

Bentuk solidaritas sosial selain membantu berbagai persiapan hajatan dan kerjasama dalam penyelenggaraan sedekah bumi dan pitulasan yang ditemukan di Tegalombo adalah

${ }^{54}$ Wawancara dengan Sholeh, tanggal 27 Desember 2011 di rumahnya di dusun Tawang Rejo.

${ }^{55}$ Freiderich Heiler, Prayer: A Study in History and Psychology of Religion, Terj. Inggris yang diringkas oleh Samuel McComb (New York: Oxford University Press, 1958), xiii.

${ }^{56} \mathrm{Do}^{\prime}$ a bersama lintas atau antar umat beragama biasanya dilakukan dengan dua cara; pertama, setiap wakil dari kelompok keagamaan membacakan do'a dengan caranya masing-masing, dan kedua, semua hadirin secara bersamaan membaca do'a dalam sebuah teks do'a. Dari dua cara tersebut, tradisi do'a bersama dalam kenduren sedekah bumi mengambil cara pertama, dimana dalam hal ini modin sebagai pimpinan mempersilahkan wakil dari kelompok Kristen untuk membacakan do'a setelah modin membacakan do'a secara Islam. 
menolong yang terkena musibah dan menziarahi yang sakit. Dalam kedua bentuk ini, masyarakat tidak memandang identitas perbedaan agama, tetapi lebih mementingkan rasa paseduluran atau persaudaraan. Bagi masyarakat Tegalombo, menolong warga yang terkena musibah atau sakit merupaka kewajiban yang merupakan kepedualian sosial. Bentuk kepedulian tersebut bisa berupa santuan maupun bisa dalam bentuk keterlibatan dalam penyelesaian masalah. ${ }^{57}$ Hal tersebut sesuai dengan ungkapan weweh tanpa kelangan (memberi tanpa kehilangan), karena keikhlasan dan keharmonisan kekeluargaan dan paseduluran yang menyebabkan simbiosis-mutualistik yang tidak mengurangi dan merugikan. ${ }^{58}$

Untuk mendapatkan gambaran lebih detail mengenai relasi dalam lingkup pekerjaan, dapat dilihat dari 3 bentuk relasi. Pertama, relasi individu dengan lingkungan pekerjaan. Relasi pekerja dengan lingkungan pekerjaan dapat dilihat dari proses penerimaan tenaga yang dibutuhkan; apakah penerimaan disebabkan keahlian atau pertimbangan lain seperti dasar kesamaan agamanya. Dalam penelitian ditemukan bahwa penerimaan seseorang dalam pekerjaan tidak mensyaratkan agama tertentu, kecuali posisi-posisi tertentu seperti modin yang mengharuskan dari kalangan Islam. Kedua, relasi pekerja dengan atasan. Dalam relasi pekerja dengan atasan atau pemberi kerja, faktor pemberian kerja selain kemampuan adalah faktor kekeluargaan dan pertemanan. Faktor agama bukanlah faktor penentu dimana seorang pekerja dapat diterima di lingkungan kerja tersebut. Ketiga, relasi antar sesama pekerja. Dalam relasi antar pekerja ini terjali solidaritas yang baik dengan tidak mempermasalahkan agama yang dianut masing-masing pihak, sehingga eksistensi agama orang lain diakui.

Pilar lain dalam membangun kerukunan umat beragama di Tegalombo adalah adanya meknisme dialog praktis dalam bentuk forum Selapanan. Adalah Dusun Tawang Rejo pada awal tahun 80-an memprakarsai sebuah forum musyawarah kampung yang kemudian dikenal pertemuan Selapanan (setiap 35 hari sekali) yang mempertemukan kelompok Kristen dengan Islam dan juga dengan pemerintah setempat. Peserta acara ini berjumlah kurang lebih 50 orang yang cukup merepresentasikan semua unsur yang ada di masyarakat. Dari unsur agama terdapat kyai, ustad, pendeta dan guru Injil. Sedangkan dari unsur pemerintahan terdapat Kepala Dusun, Kepala Rukun Warga (RW) dan Rukun Tetangga (RT) di dusun Tawang Rejo. Representasi gender ditunjukkan dengan hadirnya pegiat PKK (Pendidikan Ketrampilan Keluarga) dan juga beberapa tokoh muda Karang Taruna.

Dialog yang dibangun di Tegalombo merupakan model practice dialogue yang lebih mendiskusikan masalah-masalah masyarakat dan upaya-upaya penyelesaian masalah dalam kehidupan sehari-hari. Beberapa contoh dialog praktis yang cukup besar manfaatnya bagi kedua agama adalah terkait pelarangan operasi penyewaan biliard (bola sodok). Sekitar awal tahun 2007, warga di Tawang Rejo diresahkan dengan adanya usaha penyewaan bola

\footnotetext{
57Wawancara dengan Sungati dan Suyatno, pada tanggal 1 Januari 2013 di Tawang Rejo.

${ }^{58}$ Koentjaraningrat, Kebudayaan Jawa (Jakarta: Balai Pustaka, 1994), 436-437.
} 
sodok milik salah seorang warganya. Banyak dari warga yang resah karena selain bermain, mereka juga melakukan praktek totohan (perjudian). Selain itu, permainan tersebut juga dinilai menjadi candu yang berakibat pada penghabisan waktu bagi pemainnya, yang kebanyakan bapak-bapak, pemuda bahkan anak usia sekolah. Menanggapi berbagi keluhan tersebut, terutama yang datang dari kaum ibu, maka forum Selapanan tersebut dialamatkan untuk merespon keresahan warga. Maka, dalam forum Selapanan pada tanggal 25 Mei 2007 yang diadakan di rumah ketua RW saat itu merekomendasikan kepada Kepala Dusun untuk meminta pemilik usaha bola sodok menghentikan usaha. ${ }^{59}$

Salah satu bentuk kerjasama yang paling diingat masyarakat adalah kerjasama pengaspalan jalan desa di Tawang Rejo yang merupakan hasil swadaya masyarakat yang dimotori tokoh Islam dan Kristen. Sebagaimana yang diceritakan Sholeh, pada tahun 1990-an desa Tegalombo belum ada program pemerintah untuk pengaspalan yang masuk ke wilayah dusun. Padahal dari sisi ekonomi dusun Tawang Rejo merupakan pusat pertambakan, persawahan dan juga memiliki aset kelautan. Oleh karenanya perbaikan saran transportasi akan mempermudah masyarakat dalam pengangkutan hasil sawah, tambak maupun laut. ${ }^{60}$

Ada tiga faktor yang mendukung harmoni antar kelompok agama di Tegalombo yaitu inklusivitas beragama dan kuatnya pengaruh budaya. Idiom "Sejatine agomo kui kan podo koyo awak, mung klambine wae seng bedo / pada hakikatnya agama itu seperti tubuh yang memiliki kesamaan, hanya saja kemasannya (baju) yang berbeda" begitu lekat dalam kultur masyarakat Tegalombo. ${ }^{61}$ Idiom tersebut begitu kuat mengakar di masyarakat Tegalombo yang merawat sikap inklusif keagamaan dan perilaku keseharian mereka yang mencerminkan penerimaan terhadap perbedaan agama.

Fenomena menarik terkait penghormatan agama lain ditunjukkan pada perayaan hari besar keagamaan, dimana ketika tetangga, atau kerabat yang berbeda agama sedang merayakan hari raya keagamaan baik Natalan maupun Syawalan, keduanya saling berkunjung satu sama lain. Sikap dan tindakan kolektif ini merujuk pada teologi inklusif dan humanis yang mengakui dan mengakomodasi eksistensi setiap agama bahkan termasuk juga aliran kepercayaan dan agama-agama bumi. ${ }^{62}$ Relasi damai yang terjadi antara kelompok Islam dan Kristen di Tegalombo juga banyak dipengaruhi faktor budaya Jawa yang masih langgeng. Budaya masyarakat Tegalombo yang mencirikan perilaku rukun sangat mencolok dalam hal slametan, gotong royong, dan rembug (dialog) yang menjunjung nilai-nilai falsafah kebudayaan Jawa seperti tepo seliro, unggah-ungguh atau tata karma, lung tinulung, paseduluran

\footnotetext{
${ }^{59}$ Wawancara dengan Sungati, ketua RT 03 Tawang Rejo, pada tanggal 22 Juli 2012 di rumahnya di dusun Tawang Rejo.

${ }^{60}$ Wawancara dengan Sholeh pada tanggal 24 Mei 2012 di Tawang Rejo, Tegalombo

${ }^{61}$ Wawancara Welas (68 tahun), buruh tamba $\backslash k$, pada tanggal 31 Desember 2011 di rumahnya di dusun Tawang Rejo.

${ }^{62}$ Nurcholis Madjid dan Mun'im A. Sirry (ed.), Fiqih Lintas Agama: Membangun Masyarakat InklusifPluralis (Jakarta: Paramadina, 2005), 185.
} 
yang dipegang masyarakat sebagai panutan dalam bertutur, bersikap dan bergaul dalam konteks keluarga, kelompok sosial dan masyarakat.

Budaya tingkah laku atau etika yang masih terjaga di masyarakat Tegalombo adalah tepo saliro yaitu sikap individu untuk mengontrol pribadinya berdasarkan kesadaran diri. Tepo seliro membuat masyarakat meletakan dirinya dalam tata pergaulan sosial berdasarkan keputusan diri dan kesukarelaan hati. ${ }^{63}$ Aplikasi nilai ini ditunjukkan dengan mengunjungi kerabat atau tetangga yang sedang merayakan Natal atau Syawalan. Nilai budaya "saling" juga menjadi perekat keharmonisan masyarakat, yaitu saling bantu (lung tinulung), saling kunjung dan saling hantar makanan. Sementara budaya saling hantar makanan masih nampak ketika jelang hari raya Natal maupun Idul Fitri maupun ketika panen atau sedang mempunyai hajatan slametan. Hal ini dilandasi oleh nilai tentang perhatian dan berbagi kepada sesama yang sering dinyatakan sebagai berikut, "wonten sekedhik dipundum sekedhik, wonten kathah enggeh dipundum kathah, bila ada rezeki sedikit akan dibagi sedikit, tetapi bila ada banyak juga akan dibagi banyak juga". ${ }^{64}$

Sistem kekerabatan juga berpengaruh dalam menjaga harmoni. Sistem kekerabatan yang ada di Tegalombo menganut sistem kekerabatan keluarga Jawa pada umumnya yang menarik garis keturunannya melalui garis pria dan wanita. Pada sebagian keluarga di Tegalombo, sistem kekerabatan ini diwarnai variasi keagamaan, yaitu Islam Kristen. Variasi keagamaan yang terjadi dalam keluarga pada awalnya lahir karena bebrapa anggota keluarga pindah agama, baik melalui perkawinan atau konversi masal yang pernah terjadi paska 1965. Dalam lingkungan keluarga, perbedaan agama tidak menjadi penghalang dalam mewujudkan keutuhan keluarga, meskipun ada beberapa kasus proses pindah agama yang mendapat halangan keluarga.

Relasi antar individu atau dengan keluarga yang berbeda agama dalam konteks relasi IslamKristen di Tegalombo menampakkan kondisi apa yang disebut Mukti Ali sebagai agree in disagreement (setuju dalam perbedaan), yaitu percaya bahwa agama yang dipeluk itulah agama yang paling baik, dan mempersilahkan orang lain untuk mempercayai bahwa agama yang dipeluknya adalah agama yang paling baik. Diyakini bahwa antara satu agama dan agama lainnya, selain terdapat perbedaan, juga terdapat persamaan atau yang dikenal dengan istilah "agreement in difference". ${ }^{65}$ Kesimpulan tersebut sejalan dengan hasil penelitian Hyung Jun Kim tentang relasi Islam dan Kristen di Jawa yang juga melihat bahwa

\footnotetext{
63Suseno, Etika Jawa; Sebuah Analisa Filsafati Kebijaksanaan Hidup Jawa, 61.

${ }^{64}$ Koentjaraningrat, Kebudayaan Jawa, 441.

${ }^{65}$ A. Mukti Ali, "Ilmu Perbandingan Agama, Dialog, Dakwah dan Misi”, dalam Burhanuddin Daja dan Herman Leonard Beck (red.), Ilmu Perbandingan Agama di Indonesia dan Belanda, (Jakarta : INIS, 1992), hlm. 227-229.
} 
konsolidasi antara Muslim dan Kristiani terjadi melalui proses yang cukup panjang sampai melahirkan konsep hidup setuju dalam perbedaan. ${ }^{66}$

Dalam konteks membina kerukunan antar umat beragama, peran agama harusnya didorong untuk menjadi katalisator pencegah disintegrasi sosial masyarakat yang plural. Kekuatan agama, dapat diarahkan untuk memberikan kekuatan pada upaya penyelesaian masalah sosial. Peter L Berger misalnya mengemukakan bahwa agama merupakan sistem simbolik yang memberikan penjelasan secara meyakinkan serta komprehensif tentang realitas, tragedi, dan ketidakadilan. ${ }^{67}$ Hubungan kedua agama abrahamik ini, Islam dan Kristen tentu bukanlah suatu fenomena yang baru dalam sejarah agama. Fenomena tersebut berlangsung cukup lama yaitu 14 abad, seusia dengan kelahiran Islam itu sendiri. Rentang waktu yang cukup panjang tersebut menjadi saksi dari hubungan keduanya yang ditandai dengan periode perdamaian yang mengarah pada kerjasama dan juga konfrontasi, kesalahpahaman, dan ketidakpercayaan. Sejak itu pula kedua agama ini mempunyai bentuk hubungan ambivalen yang berpotensi konflik sekaligus saling membangun komunikasi atau dialog yang konstruktif

Dari analisa pola relasi antar umat beragama di Tegalombo, setidaknya ada beberapa situasi yang memperkuat relasi damai Islam dengan Kristen. Pertama, kondisi sosial (social conditioning). Masyarakat Tegalombo merupakan masyarakat petani dan banyak bekerja di ruang pertanian, sehingga baik Kristen maupun Muslim saling intensif bertemu dan berinteraksi dalam lingkup pemenuhan kebutuhan hidup mereka. Meskipun situasi sejarah menempatkan kedua umat beragama dalam kontestasi, namun secara sosial masyarakat tidak terpengaruh jejak sejarah dalam dendam yang berkelanjutan. Kedua, kondisi kultural (cultural setting), yaitu budaya Jawa dengan berbagai nilai atau falsafah mampu menjadi fragmen perdamaian di Tegalombo dengan merangkul kedua umat beragama dalam kesatuan budaya. Budaya Jawa seperti seperti tepo seliro menjadikan nilai kehidupan terinternalisasi dalam kehidupan mereka. Pada kenyataannya latar budaya ini membentuk sikap keagamaan masyarakat yang inklusif dan toleran dengan menghargai nilai-nilai budaya yang dianutnya.

Ketiga, kondisi politik (politic conditioning). Di Tegalombo kondisi politiknya cenderung stabil. Pergantian Kepala Desa berlangsung kondusif dan cenderung menampakkan wajah demokratis. Dalam sejarahnya, telah terjadi 5 pergantian lurah di Tegalombo, dimana dua Kepala Desa berasal dari kelompok Muslim. Salah seorang calon anggota legislatif yang bernama Sumijah, perempuan Muslim dari partai Islam, PKNU mendapatkan suara terbanyak di Tegalombo, mengungguli calon dari partai berbasis Kristen. Ketika menjadi anggota dewan, Sumijah juga dinilai bisa memberikan kontribusi yang setara yang

\footnotetext{
${ }_{6}^{6}$ Penelitian yang dilakukan di Kolojonggo tersebut melihat bagaimana hubungan antara Muslim dan Kristen. Hyung-Jun Kim, “Unto You Your Religion and Unto Me My Religion: Muslim-Christian Relations in a JavaneseVillage" dalam Journal of Social Issues in Southeast Asia, Vol. 13, No. 1 April 1998, 62-85.
}

${ }_{67}$ Peter L Berger, Langit Suci; Agama sebagai Realitas Sosial (Jakarta: LP3ES, 1991). 
umumnya bisa dinikmati masyarakat umumnya tanpa menomorsatukan kepentingan kelompoknya.

Norman Daniel dalam Islam and the West: The Making of an Image ${ }^{68}$ dan RW Southern dalam buku Western View of Islam in the Middle Ages berpendapat bahwa hubungan timbal-balik baru bisa terjadi dengan pengenalan terlebih dahulu, lalu berbicara dalam konteks hubungan sosial umat beragama. Bicara tentang prospek relasi keduanya ke depan, perlu sekiranya mencatat apa yang diwacanakan Harold Coward, yaitu agama di masa depan adalah agama-agama yang akan mampu hidup berdampingan secara menyenangkan dalam sebuah komunitas dunia. ${ }^{69}$ Menurutnya, pluralisme akan selalu menuntut manusia agar saling membagi pemahaman partikular mengenai agama dengan orang lain. Maka konteks di Tegalombo saat ini bisa menjadi salah satu model membangun dan menjaga keberlanjutan kerukunan antar umat beragama sebagaimana yang diwacanakan Harold Coward.

\section{Penutup}

Perdamaian dalam relasi antara kelompok Islam dan Kristen terbentuk karena kesadaran elit dan masyarakat kedua agama untuk hidup berdampingan dan bekerjasama. Keasadaran dan sikap tersebut dipengaruhi faktor inklusivitas dalam beragama dan nilai-nilai budaya yang mampu menghidupi toleransi antar kelompok agama yang berbeda. Hakikat relasi damai diwujudkan dengan semangat inklusivitas keagamaan dengan prinsip bahwa setiap orang berhak memeluk agama dan menjalankan ibadahnya. Sementara budaya yang menghidupi sikap dan perilaku masyarakatnya menjadi media bertemunya kedua kelompok agama untu saling berkomunikasi dan berinteraksi dalam rangka memperkuat solidaritas dan kohesi sosial dengan prinsip mengindahkan eksistensi agama lain. Nilai-nilai budaya seperti tepo seliro, unggah-ungguh, lung tinulung, saling kunjung, slametan diaktualisasikan dalam kehidupan sosial-keagamaan.

Relasi damai antara kelompok Islam dan Kristen terbangun karena pola hubungan yang dikembangkan adalah berbasis pada hubungan adat dan budaya. Penghormatan serta aktualisasi nilai budaya atau kearifan lokal menyebabkan interaksi kedua kelompok agama yang berbeda tidak saling mendominasi baik dalam aspek politik, sosial dan ekonomi. Sedangkan pola agree in disagreement menjadi kunci relasi yang harmonis antara Islam dan Kristen di Tegalombo dalam membangun pola hubungan keagamaan. Sementara kontestasi yang sesungguhnya adalah dalam perebutan dominasi penyiaran dan dakwah agama dengan teknik-teknik tertentu seperti pengajian (Islam) dan KKR (Kristen). Dalam perebutan dominasi itu, masing-masing kelompok menggunakan modal yang mereka miliki seperti modal sosial, budaya, ekonomi dan simbolik. Arena ini kerap memicu ketegangan antara kelompok Islam dan Kristen yang diakibatkan perbedaan konsepsi, saling curiga dan lemahnya mekanisme lokal dalam mengelola konflik antar kelompok agama.

${ }^{68}$ Norman Danie, Islam and The West: The Making of an Image (Oxford: Oneworld Publication, 1997).

${ }^{69}$ Coward, Harold, Pluralisme: Tantangan bagi Agama Agama. Yogyyakarta: Penerbit Kanisius, 1994). 
Kontestasi antar kelompok agama berbeda sebagaimana yang terjadi di Tegalombo maupun wilayah lain di Indonesia meskipun telah bisa diredam, namun hal itu bisa muncul kembali sewaktu waktu di masa datang jika tidak diantisipasi lebih dini. Maka sangat diperlukan ruang-ruang komunikasi dan interaksi antar umat beragama yang berbeda untuk menjembatani jika ada perbedaan kepentingan dan juga munculnya isu yang bisa memecah integrasi keduanya. Dengan demikian, dialog-dialog antar lintas agama dan berbagai aliran dan pemahaman dalam internal agama itu sendiri perlu lebih diintensifkan kembali. Hal ini untuk mengantisipasi gejolak konflik yang bisa muncul kapan saja. Menghidupkan kembali forum-forum di masyarakat yang menjembatani dialog antar kelompok bebeda sangat mendesak dilakukan untuk menyebarkan pemahaman saling menghormati dan menerima perbedaan agama demi mencipatkan dan melanggengkan hubungan harmonis antar umat beragama.

\section{Daftar Pustaka}

Al Qurtuby, Sumanto."Pluralisme, Dailog dan Peacebuilding Berbasis Agama di Indonesia", Dalam Elza Peldi Taher (ed), Merayakan Kebebasan Beragama: Bunga Rampai 70 Tahun Johan Effendi. Jakarta: ICRP bekerjasama dengan Penerbit Kompas, 2009.

Amstrong, Karen, Holy War: The Crusades and Their Impact on Today's World. New York: Anchor Books, 2001.

Aritonang, Jan. S. Sejarah Perjumpaan Islam dan Kristen. Jakarta: BpK Gunung Mulia, 2006.

Arifin, Syamsul dan Nafik Muthohirin. "The Viewpoint of the Young Muhammadiyah Intellectuals Towards the Religious Minority Groups in Indonesia". TEOSOFI: Jurnal Tasawuf dan Pemikiran Islam. Vol.9 No. 2. Desember, 2019.

Azra, Azyumardi dkk, Ensiklopedi Islam 4. Jakarta; Ichtiar Baru Van Hoeve, 2001. Azra, Azyumardi. Konteks Berteologi di Indonesia. Jakarta: Paramadina, 1999.

Benda, Harry , Bulan Sabit Matahari Terbit. Jakarta: Pustaka Jaya, 1985.

Berger, Peter L. Langit Suci; Agama sebagai Realitas Sosial. Jakarta: LP3ES, 1991.

Boland, B.J. Pergumulan Islam di Indonesia. Jakarta: Grafiti Press, 1985.

Bouma, Garry D. "The Challenge of Religious Revitalization and Religious Diversity", dalam Briyan S. Turner (Ed.). Religious Diversity and Civil Society (Oxford: The Bardwell Press, 2008.

Coward, Harold, Pluralisme: Tantangan bagi Agama Agama. Yogyyakarta: Penerbit Kanisius, 1994

Danie, Norman. Islam and The West: The Making of an Image. Oxford: Oneworld Publication, 1997Effendi, Djohan. Pembaharuan Tanpa Membongkar Tradisi: Wacana Keagamaan di Kalangan Generasi Muda NU Masa Kepemimpinan Gus Dur. Jakarta: Penerbit Buku Kompas, 2010.

Geertz, Clifford. Agama di Jawa; Konflik dan Integrasi, dalam Roland Robertson (ed), Agama: Dalam Analisa dan Intepretasi Sosiologi. Terj. Acmad Fedyani Syaifuddin. Jakarta: CV Rajawali, 1988.

.Religion as a Cultural System", dalam, The Intepretation on of Cultures: Selected Essays. Oxford: Fontana Press, 1993. 
The Religion of Java. Glencoe, IL: Free Press, 1960.

Hasani, Ismail. Radikalisme Agama di Jabodetabek \& Jawa Barat. Jakarta: Publikasi Setara Institute, 2011.

Heiler, Freiderich, Prayer: A Study in History and Psychology of Religion, Terj. Inggris yang diringkas oleh Samuel McComb. New York: Oxford University Press, 1958.

Koentjaraningrat, Kebudayaan Jawa (Jakarta: Balai Pustaka, 1994

Kristiawan, Danang "Mistisme dan Pembebasan Kyai Ibrahim Tunggul Wulung", Makalah di http://elsaonline.com/?p=1607 diakses pada 14 Februari 2015.

Majid, Nurcholis. Islam Agama Kemanusiaan: Membangun Tradisi dan Visi baru Indonesia. Jakarta: Yayasan Wakaf Paramadina, 1995.

. "Masyarakat Madani dan Investasi Demokrasi: Tantangan dan Kemungkinan". Dalam Ahmad Baso, Civil Society versus Masyarakat Madani: Arkeologi Pemikiran "civil Society" dalam Islam Indonesia. Bandung: Pustaka Hidayah, 1999.

Mujiburrahman. Feeling Threatened: Muslim-Christian Relations in Indonesia's New Order. Leiden: Amsterdam University Press, 2006

Muthohirin, Nafik. Fundamentalisme Islam: Gerakan dan Tipologi Pemikiran Aktivis Dakwah Kampus (Jakarta: IndoStrategi, 2014)

. "Radikalisme Islam dan Pergerakannya di Media Sosial". Afkaruna: Indonesian Interdisciplinary Journal of Islamic Studies. Vol. 11. No.2 (2015).

. "The Viewpoint of the Young Muhammadiyah Intellectuals towards the Religious Minority Groups in Indonesia". TEOSOFI: Jurnal Tasawuf dan Pemikiran Islam. Vol. 9. No. 2 (2019)

Pruitt, Dean G. dan Jeffrey Z. Rubin, Teori Konflik Sosial, terj. Helly P. Sutjipto dan Sri Mulyati. Yogyakarta: Pustaka Pelajar, 2004.

Sudarta. Konflik Islam-Kristen, Menguak Akar Masalah Hubungan Antar umat Beragama di Indonesia. Semarang: Pustaka Rizki Putra, 1999.

Suseno, Franz Magnis.Etika Jawa; Sebuah Analisa Filsafati Kebijaksanaan Hidup Jawa. Jakarta: Gramedia, 1984.

Soekoco dan Lawrence M. Yoder. Tata Injil di Bumi Muria. Semarang: Pustaka Muria berdasarkan pesanan dari sinode GITJ, 2010.

Walzer, Michael. On Toleration. New Haven and London: Yale University, 1997.

Zikmund, Barbara Brown "Dialog Agama-Agama dalam Konteks Misionarisme Baru", dalam Komarudin Hidayat dan Ahmad Gaus AF (Ed.), Passing Over: Melintasi Batas Agama. Jakarta: Gramedia dan Paramadina, 1998 